\title{
Implementing marine organic aerosols into the GEOS-Chem model
}

\author{
B. Gantt ${ }^{1, *}$, M. S. Johnson ${ }^{2}$, M. Crippa ${ }^{3, * *}$, A. S. H. Prévôt ${ }^{3}$, and N. Meskhidze ${ }^{1}$ \\ ${ }^{1}$ Department of Marine, Earth, and Atmospheric Sciences, North Carolina State University, Raleigh, NC, USA \\ ${ }^{2}$ Earth Science Division, NASA Ames Research Center, Moffett Field, CA, USA \\ ${ }^{3}$ Laboratory of Atmospheric Chemistry, Paul Scherrer Institute, Villigen, Switzerland \\ *now at: National Exposure Research Laboratory, Office of Research and Development, US Environmental Protection \\ Agency, Research Triangle Park, NC, USA \\ *** now at: European Commission, Joint Research Centre, Institute for Environment and Sustainability, Air and Climate Unit, \\ Ispra, Italy
}

Correspondence to: B. Gantt (bdgantt@gmail.com)

Received: 12 August 2014 - Published in Geosci. Model Dev. Discuss.: 9 September 2014

Revised: 27 January 2015 - Accepted: 10 February 2015 - Published: 17 March 2015

\begin{abstract}
Marine-sourced organic aerosols (MOAs) have been shown to play an important role in tropospheric chemistry by impacting surface mass, cloud condensation nuclei, and ice nuclei concentrations over remote marine and coastal regions. In this work, an online marine primary organic aerosol emission parameterization, designed to be used for both global and regional models, was implemented into the GEOS-Chem (Global Earth Observing System Chemistry) model. The implemented emission scheme improved the large underprediction of organic aerosol concentrations in clean marine regions (normalized mean bias decreases from $-79 \%$ when using the default settings to $-12 \%$ when marine organic aerosols are added). Model predictions were also in good agreement (correlation coefficient of 0.62 and normalized mean bias of $-36 \%$ ) with hourly surface concentrations of MOAs observed during the summertime at an inland site near Paris, France. Our study shows that MOAs have weaker coastal-to-inland concentration gradients than seasalt aerosols, leading to several inland European cities having $>10 \%$ of their surface submicron organic aerosol mass concentration with a marine source. The addition of MOA tracers to GEOS-Chem enabled us to identify the regions with large contributions of freshly emitted or aged aerosol having distinct physicochemical properties, potentially indicating optimal locations for future field studies.
\end{abstract}

\section{Introduction}

With the decrease in anthropogenic emissions of particulate matter in many industrialized countries, an increased emphasis has been placed on understanding the inventory of natural aerosol sources (Zare et al., 2014). Natural aerosols also have an important climatic impact, as long-term changes in emissions and the feedbacks on meteorology can lead to a global mean radiative perturbation approaching $1 \mathrm{~W} \mathrm{~m}^{-2}$ (Carslaw et al., 2010). Marine-sourced organic aerosols (MOAs), which have been observed at concentrations $>1.0 \mu \mathrm{g} \mathrm{m}^{-3}$ (Ovadnevaite et al., 2011) and whose estimated global emissions are comparable to that of fossil fuel burning (Spracklen et al., 2008), are one type of natural aerosol with air quality and climate significance (Gantt and Meskhidze, 2013). For instance, MOAs affect the surface mass, cloud condensation nuclei, and ice nuclei concentrations in clean marine regions (O'Dowd et al., 2004; Meskhidze et al., 2011; Westervelt et al., 2012; Burrows et al., 2013; Partanen et al., 2014). Uncertainty in the chemical composition of sea spray aerosol (SSA) has also been shown to play an important role in determining their climate impact (Tsigaridis et al., 2013). Therefore, it is important for chemical transport and climate models to take MOA emissions and physicochemical processes into consideration.

With instrumentation such as the high-resolution timeof-flight aerosol mass spectrometer (HR-ToF-AMS), source profiles of ambient organic aerosols can be derived using positive matrix factorization (PMF) techniques (Lanz et al., 
2007; Zhang et al., 2011). Chang et al. (2011) derives a marine-sourced biogenic PMF factor based on high levels of organic sulfur species observed at several coastal locations affected by marine air masses. Applying a HR-ToFAMS/PMF analysis similar to Chang et al. (2011) to chemically identify MOAs, Crippa et al. (2013a) find that on average $16 \%$ of the total summertime organic aerosol mass $\sim 20 \mathrm{~km} \mathrm{SW}$ of Paris had a marine source despite being $>150 \mathrm{~km}$ from the English Channel and Atlantic Ocean. Concurrent summertime HR-ToF-AMS measurements in the core of the Paris metropolitan area reported by Crippa et al. (2013b) indicate that $13 \%$ of the total OA (organic aerosol) had a marine source. Other studies have identified similar MOA-specific HR-ToF-AMS mass spectra in other locations (Ovadnevaite et al., 2011; Schmale et al., 2013) to better understand its sources. Unlike typical organic aerosol observations, these HR-ToF-AMS spectra allow for the model evaluation of marine organic aerosol concentrations separate from the surrounding terrestrial/anthropogenic emissions. Although some mathematical mixing between sources cannot be excluded in the HR-ToF-AMS/PMF analysis, Crippa et al. (2013b) obtained similar MOA mass concentrations and percentage contributions when HR-ToFAMS measurements were combined with that of a highsensitivity proton transfer reaction mass spectrometer (HSPTR-MS).

Although secondary organic aerosol (SOA) precursors can have a marine source (Shaw et al., 2010), marine primary organic aerosols (POAs) have been shown to be the major contributor to organic aerosol mass concentrations over marine regions (Arnold et al., 2009; Gantt and Meskhidze, 2013). The observation of clean marine organic aerosol surface concentrations having the same seasonal cycle as that of surface chlorophyll $a$ concentrations ([chl $a]$ ) (Cavalli et al., 2004; Sciare et al., 2009) led to the development of marine POA emission parameterizations based on a [chl $a]$-derived or-

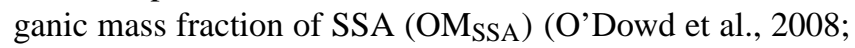
Vignati et al., 2010). Gantt et al. (2012) compare several marine POA emission schemes in a global model, finding that the schemes with a strong dependence on $[\mathrm{chl} a]$ had concentrations most similar to seasonal observations. However, the use of [chl $a$ ] as a proxy for OM SSA $_{\text {has come into question }}$ by several laboratory- and field-based studies showing that oceanic organic carbon concentration might be more closely related to organic enrichment of SSA (Prather et al., 2013; Quinn et al., 2014). Burrows et al. (2014) models the organic enrichment of SSA using several classes of organic compounds from a biogeochemical ocean model, finding that $\mathrm{OM}_{\mathrm{SSA}}$ is related to [chl $a$ ] only in certain regions. Rinaldi et al. (2013) finds that [chl $a$ ] was more highly correlated with $\mathrm{OM}_{\mathrm{SSA}}$ than oceanic organic carbon, but suggested an 8-day time lag to account for biological processes responsible for the production of transferable organic materials during the phytoplankton bloom evolution. Recent field studies have suggested that other physical/biological processes af- fecting sea spray aerosol production may also be missing in current emission parameterizations, such as the diurnal variability in sea spray aerosol generated from biologically productive waters (Long et al., 2014). Like most global estimates of marine POA emissions, we use satellite-derived [chl $a]$ as a proxy for $\mathrm{OM}_{\mathrm{SSA}}$ due to the lack of consensus of factors driving organic enrichment of sea spray aerosol, strong correlations observed between organic aerosol concentrations and [chl $a]$ in clean marine environments, and scarcity of global oceanic data sets for use in chemical transport models.

In addition to emissions, the physicochemical treatment of terrestrial and marine organic aerosols in the atmosphere affects their predicted concentrations. A summary of past modeling studies showed that the aging of marine and terrestrial organic aerosols (calculated either by e-folding times, microphysics, or oxidant/sulfate concentrations) is highly variable spatially and temporally with global averages ranging from $\sim 1$ to 5 days (Huang et al., 2013). Spracklen et al. (2008) finds that doubling the marine organic aerosol e-folding time for conversion from hydrophobic to hydrophilic in GEOSChem (Global Earth Observing System Chemistry; thus decreasing the aerosol aging process) from 1.2 to 2.4 days increased surface MOA concentrations by $\sim 15 \%$ globally due to decreased in-cloud scavenging. Westervelt et al. (2012), on the other hand, did not predict significant differences in surface concentrations after changing the aging timescale of marine organic aerosols from 1.5 to 4.5 days in the GISS II prime model. Huang et al. (2013) found that several detailed aging schemes (including oxidant and condensationcoagulation aging) for terrestrial carbonaceous aerosols in GEOS-Chem led to a variable hydrophobic to hydrophilic conversion lifetime, ranging from $<1$ to +8 days. Modeling studies have typically treated the chemistry and physics of marine organic aerosols within the atmosphere like that of terrestrial organic aerosols due to the lack of understanding of marine boundary layer aerosol processes (Meskhidze et al., 2013).

In this study, we used the GEOS-Chem model to quantify the contribution of organics associated with submicron SSA emissions to global MOA concentrations. GEOS-Chem is a global chemical transport model widely used for simulating aerosol and gas emission processes, atmospheric chemistry, regional- and global-scale pollution transport, and for providing boundary conditions to regional chemical transport models (CTMs). Global emissions estimates of marine POA and intercomparison of multiple emission parameterizations have been previously performed using older versions of GEOS-Chem (Spracklen et al., 2008; Lapina et al., 2011; Gantt et al., 2012); these studies had variable success replicating the observed surface organic aerosol concentrations in clean marine environments. Nevertheless, analysis of model results indicates that addition of a marine primary organic source brought the model results closer to observations. Despite these previous studies, the current version of the GEOS-Chem model does not include online marine POA 
emissions or MOA tracers in the default settings. The overall objective of this study is to expand upon Gantt et al. (2012) by implementing an online marine POA emission parameterization into the current version of GEOS-Chem (v9-02) that can be easily used in the default setting with the following characteristics: (1) adds minimal computational expense, (2) capable of being used for all GEOS-Chem model domains/simulation periods, and (3) treated with unique tracers capable of explicit atmospheric aging and tracking. During this study the emission parameterization is tested for the global and nested regional model domains and evaluated with new data sets having advanced MOA chemical characterization and widespread global coverage. Finally, the model is used to predict global surface concentrations, ocean-land concentration gradients, and relative contributions of nascent (freshly emitted) and aged marine organic aerosols.

\section{Model configuration}

\subsection{GEOS-Chem}

We used v9-02 of the global CTM GEOS-Chem (http:// geos-chem.org/) with $2^{\circ} \times 2.5^{\circ}$ (latitude - longitude) horizontal resolution and 47 vertical hybrid sigma-pressure levels, driven by GEOS-5 assimilated meteorology from the NASA Global Modeling Assimilation Office (GMAO). The model was run with a full chemistry configuration, which includes $\mathrm{H}_{2} \mathrm{SO}_{4}-\mathrm{HNO}_{3}-\mathrm{NH}_{3}$ aerosol thermodynamics (ISORROPIA II) coupled to an $\mathrm{O}_{3}-\mathrm{NO}_{\mathrm{x}}$-hydrocarbonaerosol chemical mechanism (Bey et al., 2001; Park et al., 2004; Fountoukis and Nenes, 2007). Terrestrial emissions of carbonaceous aerosols were based on Bond et al. (2007) (biofuel and fossil fuel) and daily wildfire emissions from version 3 of the Global Fire Data (GFED3) database (van der Werf et al., 2010). Secondary organic aerosol formation was included in our simulations based on Pye et al. (2010). Although marine-source SOAs have been shown to contribute to the organic aerosol mass concentration in some regions (Decesari et al., 2011; Fu et al., 2013; Hu et al., 2013), we did not consider oceanic emissions of SOA precursors because they have uncertain global emission inventories ranging from 0.32 to $11.6 \mathrm{Tg} \mathrm{C} \mathrm{yr}^{-1}$ for isoprene and $0.013-29.5 \mathrm{Tg} \mathrm{C} \mathrm{yr}^{-1}$ for $\alpha$-pinene (Sinreich et al., 2010; Luo and Yu, 2010; Miyazaki et al., 2014). Furthermore, marine-source SOA formation mechanisms are not well known (Bikkina et al., 2014) and when modeled have been estimated to contribute less than primary sources to the organic aerosol budget in many marine regions (Arnold et al., 2009; Fu et al., 2013). Sea-salt aerosols in the model were emitted in two bin sizes (fine mode ranging from 0.02 to $1.0 \mu \mathrm{m}$ in diameter and coarse mode ranging from 1.0 to $16.0 \mu \mathrm{m}$ in diameter) as a function of a power relationship with $10 \mathrm{~m}$ winds speeds $\left(U_{10}\right)$ following the formulation of Gong (2003) and includes the 3rd-order polynomial dependence on sea surface tempera- ture (SST) as described by Jaeglé et al. (2011). Within this model setup, we introduced a hydrophilic and hydrophobic tracer for marine POA. Differences between the hydrophilic and hydrophobic tracers involved depositional processes: wet deposition, which includes rainout and scavenging from convective updrafts, was applied only to the hydrophilic tracers (Liu et al., 2001). Dry deposition in the model was based on the resistance-in-series scheme described in Wesely (1989), with the surface resistances for aerosols following the work of Zhang et al. (2001). A detailed description of the various marine POA emission schemes and model treatment of the marine POA tracers is given in Sect. 2.2. A yearlong GEOS-Chem simulation for 2009 was performed for the global domain, with a nested simulation of the European domain $\left(0.5^{\circ} \times 0.67^{\circ}\right)$ performed for July 2009 in order to show ocean-continental concentration gradients and compare with novel measurements of marine organic aerosol collected near Paris, France. The $3 \mathrm{~h}$ dynamic boundary conditions for the nested model run were prescribed from the global GEOSChem simulation.

\subsection{Marine POA emission}

Submicron marine POA emissions implemented into GEOSChem were based on the top-down parameterization developed by Gantt et al. (2012), which compared several marine POA emission schemes using an older version of GEOS-Chem (v8-01-01). The top-down parameterization from Gantt et al. (2012) updated the Gantt et al. (2011) emission scheme by (1) increasing the $\mathrm{OM}_{\mathrm{SSA}}$ dependence on [chl $a$ ] and $U_{10}$ to strengthen the correlation between model-predicted and observed organic aerosol surface concentrations at Mace Head, Ireland, and Amsterdam Island over several years; and (2) scaling the total marine POA mass emission rate $\left(E_{\mathrm{POA}}\right)$ to minimize the bias of GEOSChem-predicted surface concentrations with seasonal observations at Mace Head and Amsterdam Island. In addition to improving the prediction of seasonal observations, we used the Gantt et al. (2012) top-down parameterization because it yields better predictions of both monthly and seasonal concentrations of organic aerosol over coastal regions, and hourly surface concentrations during a MOA plume event (Ovadnevaite et al., 2011). The Gantt et al. (2012) top-down emission parameterization is given as follows:

$$
\begin{aligned}
& \mathrm{OM}_{\mathrm{SSA}}\left(\operatorname{chl} a, U_{10}, D_{\mathrm{p}}\right)= \\
& \frac{\left(\frac{1}{1+\exp \left(3(-2.63[\operatorname{chl} a])+3\left(0.18\left(U_{10}\right)\right)\right)}\right)}{1+0.03 \exp \left(6.81 D_{\mathrm{p}}\right)} \\
& +\frac{0.03}{1+\exp \left(3(-2.63[\operatorname{chl} a])+3\left(0.18\left(U_{10}\right)\right)\right)},
\end{aligned}
$$

$E_{\mathrm{POA}}\left(\operatorname{chl} a U_{10} D_{\mathrm{p}}\right)=6 \times V_{\mathrm{SSA}} \times \mathrm{OM}_{\mathrm{SSA}} \times \rho_{\mathrm{SSA}}$, 
where $D_{\mathrm{p}}$ is the sea spray particle dry diameter $(\mu \mathrm{m}), V_{\mathrm{SSA}}$ is the volume emissions $\left(\mathrm{cm}^{3} \mathrm{~m}^{-2} \mathrm{~s}^{-1}\right)$ of sea spray aerosol according to the Gong et al. (2003) source function with SST dependence of Jaeglé et al. (2011), $\rho_{\text {SSA }}$ is the apparent density $\left(\mathrm{g} \mathrm{cm}^{-3}\right)$ of the sea spray aerosol calculated as a function of the organic and sea-salt mass fractions, $E_{\mathrm{POA}}$ has units of molecules per square centimeter per second (molecules $\mathrm{cm}^{-2} \mathrm{~s}^{-1}$ ) after conversion from grams per square meter per second $\left(\mathrm{g} \mathrm{m}^{-2} \mathrm{~s}^{-1}\right)$ using a molecular weight of carbon, and [chl $a$ ] and $U_{10}$ have units of milligrams per cubic meter $\left(\mathrm{mg} \mathrm{m}^{-3}\right)$ and meters per second $\left(\mathrm{m} \mathrm{s}^{-1}\right)$, respectively.

The daily-average [chl $a$ ] used in this study to calculate marine POA emissions in GEOS-Chem was from temporally interpolated, monthly-average MODIS/Aqua-derived [chl $a$ ] at $1 / 12^{\circ}$ horizontal resolution that was spatially averaged online to fit the global and European domains. Although the year 2009 was simulated for this study due to the availability of inland marine organic aerosol measurements (Crippa et al., 2013a), model-ready MODIS/Aqua [chl $a$ ] inputs were generated for 2005-2011 and can easily be expanded to include additional years/satellite data sets. Similar to terrestrial primary organic aerosols in GEOS-Chem, marine POAs were emitted as hydrophobic and converted to hydrophilic in the atmosphere with an e-folding time of 1.15 days (Cooke et al., 1999). This was consistent with the observation that freshly emitted submicron marine primary organic aerosols are water insoluble colloids and aggregates (Facchini et al., 2008; Collins et al., 2013) but can become more water soluble through atmospheric aging (Rinaldi et al., 2010; Decesari et al., 2011). Marine POA was emitted as an external mixture with sea-salt aerosols based on evidence that organics exist separately from sea-salt in aerosols below $200 \mathrm{~nm}$ in diameter (Bigg and Leck, 2008; Prather et al., 2013), although the implementation of MOA tracers allows for future changes in the chemical treatment.

\section{Results}

\subsection{Seasonal concentrations}

Figure 1 shows surface, averaged $(\sim 100 \mathrm{~m}$ above ground level) MOA mass concentrations (left column) and the contribution of marine-source organic aerosol to total (terrestrial + marine) submicron organic aerosol surface mass (right column) predicted by GEOS-Chem. Vast regions of the Northern Atlantic, Northern Pacific, and Southern Oceans had summertime concentrations (up to $1000 \mathrm{ng} \mathrm{m}^{-3}$ ) up to a factor of 5 higher than the wintertime concentrations $\left(<200 \mathrm{ng} \mathrm{m}^{-3}\right)$ due primarily to the increase in emissions (see Fig. S1 in the Supplement) associated with the seasonal cycle of $[\mathrm{chl} a]$. This strong seasonal cycle of organic aerosol concentrations was consistent with long-term observations at several midlatitude coastal locations (Cavalli et al., 2004;

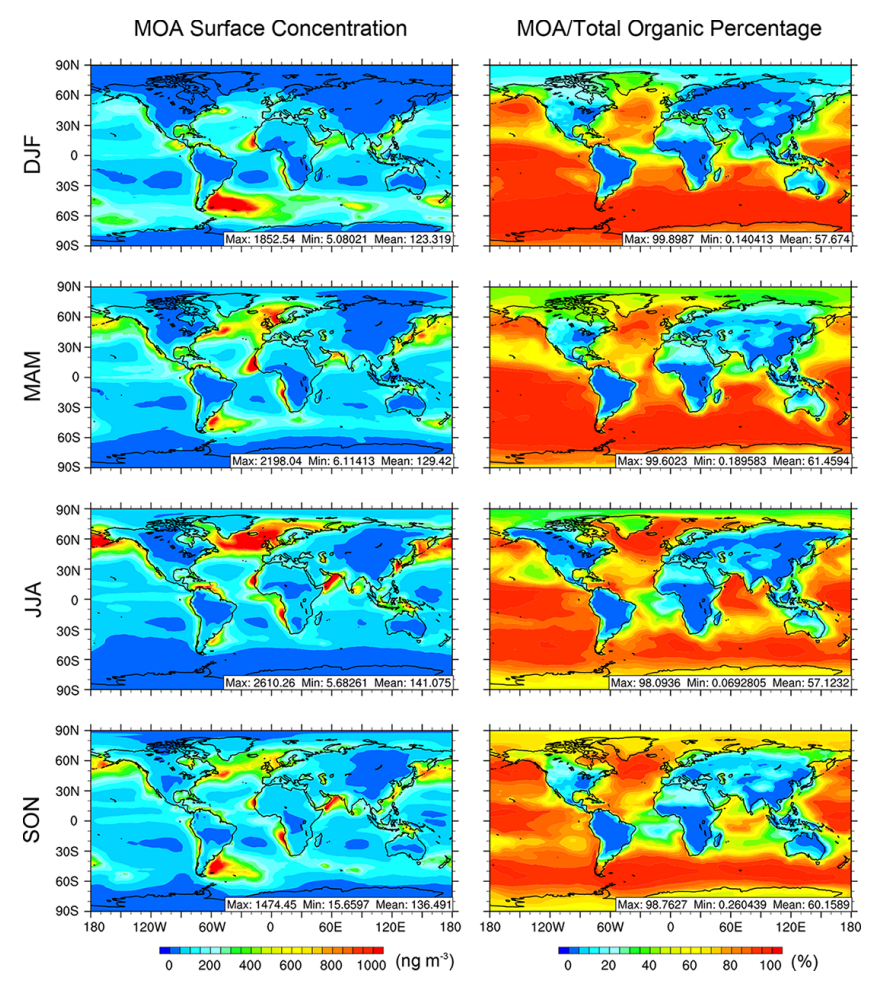

Figure 1. Seasonally averaged submicron MOA surface concentrations and percentages of total submicron organic aerosol (marine + primary anthropogenic + biomass burning + secondary) with a marine source as predicted by GEOS-Chem for 2009.

Spracklen et al., 2008; Sciare et al., 2009) having summertime organic aerosol concentrations of a factor of $2-5$ higher compared to wintertime. Similarly, the MOA factor observed in Paris in the summertime by Crippa et al. (2013a, b) was not detected in the wintertime (Crippa et al., 2013b, c) because the contribution to total OA was below the detection limit of $\sim 20 \mathrm{ng} \mathrm{m}^{-3}$ (DeCarlo et al., 2006). The summertime MOA concentrations and marine POA emissions predicted by GEOS-Chem were higher in the Northern Hemisphere than in the Southern Hemisphere (see Figs. 1 and S1) despite having lower SSA emissions; this was related to the higher $\mathrm{OM}_{\mathrm{SSA}}$ in the Northern Hemisphere which is positively related to [chl $a$ ] and negatively related to $U_{10}$ using a logistic curve for both relationships. According to Fig. 1, equatorial oceanic regions revealed little seasonal variation in marine organic aerosol concentrations, with low concentrations over oligotrophic oceans and high concentrations over productive coastal regions throughout the year. Inland regions far from the ocean had very low MOA concentrations $\left(<50 \mathrm{ng} \mathrm{m}^{-3}\right)$ throughout the year, while coastal areas typically have concentrations of up to $200 \mathrm{ng} \mathrm{m}^{-3}$.

Figure 1 (right column) shows that marine-source organic aerosols typically contributed $>80 \%$ of the total (terrestrial + marine) submicron organic aerosol burden over remote oceanic regions such as the Southern Ocean and equa- 


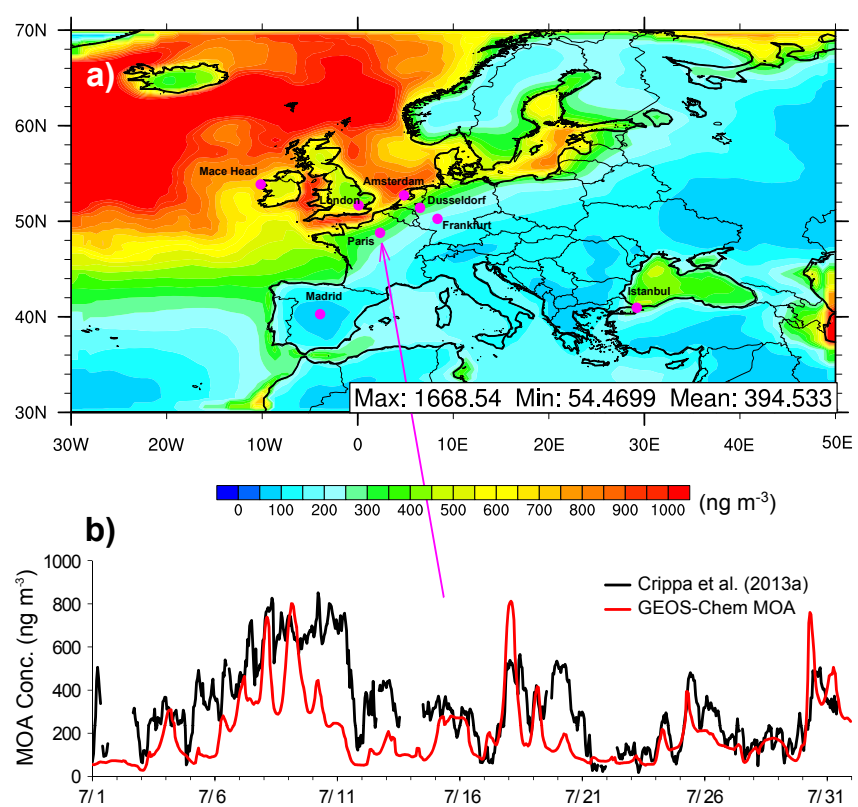

Figure 2. (a) Average submicron surface concentration of MOA for July 2009 in the nested Europe GEOS-Chem domain and the (b) time series of the observed and predicted marine organic aerosol concentration near Paris, France, as reported by Crippa et al. (2013a). Evaluation of the GEOS-Chem MOA with the Crippa et al. (2013a) observations gives a correlation coefficient of 0.62 , mean bias of $-120 \mathrm{ng} \mathrm{m}^{-3}$, and normalized mean bias of $-36 \%$.

torial Pacific for much of the year. In coastal regions downwind of terrestrial aerosol sources, the ratio of marine-source to total submicron organic aerosols $\left(F_{\mathrm{MOA}}\right)$ was much lower $(<40 \%)$ than remote marine regions. Figure 1 also shows that the seasonal cycle of $F_{\mathrm{MOA}}$ for many inland and coastal regions (i.e., Arctic Ocean coastline, European continent) was different from that of surface concentrations (left column) because of the strong seasonal cycle of terrestrial organic aerosol concentrations from biomass burning and SOA formation. Compared to a previously published map of $F_{\mathrm{MOA}}$ from the TM4-ECPL model (see Fig. 4c in Myriokefalitakis et al., 2010), GEOS-Chem predicted higher values (up to $20 \%$ vs. $<5 \%$ ) widespread over terrestrial regions. Similarly, GEOS-Chem predicted higher $F_{\mathrm{MOA}}$ than Myriokefalitakis et al. (2010) over most remote oceanic regions $(>60 \%$ vs. 10-50\%). These discrepancies were likely caused by a number of differences including marine POA emission schemes (Gantt et al., 2012 vs. Vignati et al., 2010), SOA formation mechanisms, atmospheric aging schemes of hydrophobic POA, and the inclusion of supermicron terrestrial organic aerosols in $F_{\mathrm{MOA}}$ by Myriokefalitakis et al. (2010).

The nested GEOS-Chem simulation in this study illustrated the MOA concentration gradient from coastal to inland regions. Figure 2a shows a sharp concentration gradient over Europe, decreasing from 1000 to $200 \mathrm{ng} \mathrm{m}^{-3}$ within $\sim 250 \mathrm{~km}$ of the northern Atlantic Ocean coastline. Three major cities roughly 25,200 , and $370 \mathrm{~km}$ from the coast, Amsterdam, Düsseldorf, and Frankfurt, had monthly-average surface concentrations of marine organic aerosol decreasing exponentially from 670 to 280 to $180 \mathrm{ng} \mathrm{m}^{-3}$ for July 2009 , respectively (see Fig. 2). For these three cities, the modeled $F_{\mathrm{MOA}}$ decreased from 37 to 12 to $8 \%$, respectively. Although Düsseldorf and Frankfurt had significantly lower $F_{\text {MOA }}$ than Amsterdam, these inland cities still had $\sim 10 \%$ of their submicron organic aerosol mass contributed by a marine source. GEOS-Chem predicted that of the 10 largest cities in Europe, three (Istanbul, London, and Madrid) have marine-source organic aerosols making up $>10 \%$ of the total (terrestrial + marine) surface organic aerosol concentration. The coastal gradient of marine organic aerosol concentrations was not as sharp as that of submicron sea-salt aerosol (see Fig. S2) due to the poor in-cloud scavenging of hydrophobic nascent marine organic aerosol. Relatively weak concentration gradients between the ocean and land over the western coast of Ireland suggested that measurements at Mace Head, Ireland, are likely to be characteristic of the open ocean (Rinaldi et al., 2009). The sharpest marine organic aerosol concentration gradients in Fig. 2a occurred in mountainous regions of Norway due to the steep terrain.

\subsection{Comparison with surface observations}

The time series in Fig. 2b shows a comparison of hourly marine organic aerosol surface concentrations near Paris, France, during July 2009 from the observations made by Crippa et al. (2013a) and GEOS-Chem predictions. The high temporally resolved MOA concentrations derived from HRToF-AMS measurements in Paris allowed for an evaluation of model-predicted MOA with two unique characteristics: the observations are (1) at the same hourly timescale of the model output and (2) at an inland site without the influence of terrestrial and anthropogenic sources. Figure $2 b$ shows that with a few exceptions, GEOS-Chem was able to capture both the magnitude and temporal variability of marine organic aerosol concentrations (correlation coefficient $=0.62$ and normalized mean bias $=-36 \%$ ). The period of highest observed and GEOS-Chem-predicted MOA concentrations (6-9 July) also had low black carbon concentrations $\left(<1 \mu \mathrm{g} \mathrm{m}^{-3}\right)$ and air masses originating in the North Atlantic Ocean. Back trajectories (not shown) were derived from NOAA's hybrid single-particle Lagrangian integrated trajectory (HYSPLIT) model (Draxler and Rolph, 2014). In the days immediately following this period (10-11 July), the measured MOA remained high while GEOS-Chem predicted a rapid decrease in concentrations; this discrepancy may be due in part to the different definitions of MOA in GEOSChem and Crippa et al. (2013a). The HR-ToF-AMS measurements from Crippa et al. (2013a) do not differentiate between primary and secondary sources of MOA and the current version of GEOS-Chem does not include SOA production from marine-source precursor species. Therefore, consider- 

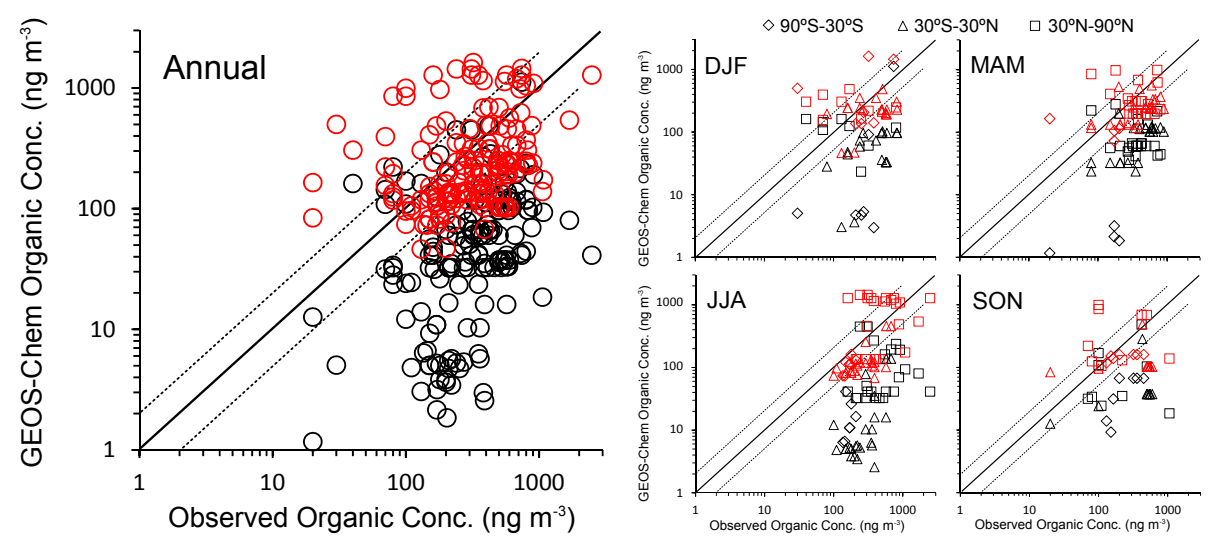

Figure 3. Global comparison of observed clean marine organic aerosol concentrations compiled by Gantt and Meskhidze (2013) and GEOSChem-predicted terrestrial (black) and total (marine + terrestrial, in red) submicron organic aerosol concentrations. The solid and dotted lines represent the $1: 1$ line, $1: 2$ and $2: 1$ lines, respectively.

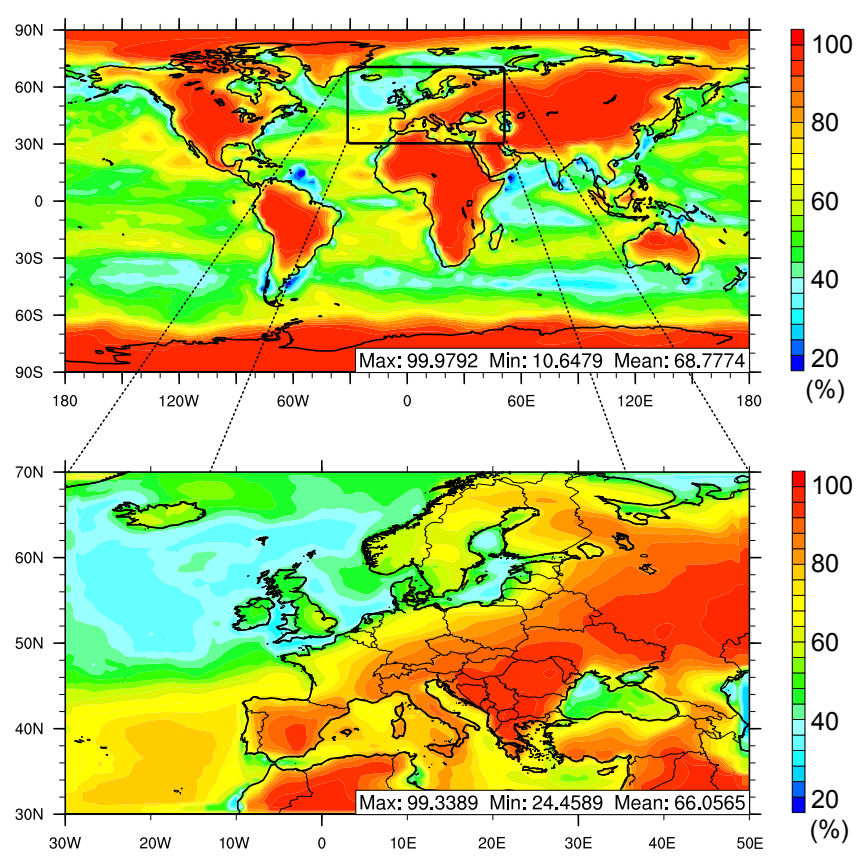

Figure 4. Percentage of the submicron MOA concentration predicted by GEOS-Chem to be hydrophilic (aged) for July 2009.

able discrepancies between measurements and model predictions are expected when SOA of marine origin contributes a sizable fraction of MOA mass. Doubling the hydrophobic to hydrophilic conversion timescale in GEOS-Chem from the baseline value of 1.15 days to 2.3 days resulted in slightly improved MOA predictions near Paris (correlation coefficient $=0.64$ (vs. 0.62 for 1.15-day aging) and normalized mean bias $=-26 \%$ (vs. $-36 \%)$ ).

In addition to the comparison with hourly concentrations of AMS-derived marine organic aerosol at an inland site, we have also evaluated terrestrial and total organic aerosol concentrations predicted by GEOS-Chem to a recently published compilation of surface organic aerosol concentrations in clean marine conditions (defined as having black carbon concentrations $<0.05 \mu \mathrm{g} \mathrm{m}^{-3}$ ) from Gantt and Meskhidze (2013). Figure 3 shows a scatterplot of the observational data compared to GEOS-Chem surface concentrations matched by location and month(s) but representing different years (observations span 1973-2009 while GEOS-Chem predictions are for 2009). During baseline simulations when only terrestrial organic aerosol emissions were included (black circles in Fig. 3), GEOS-Chem exhibited a strong model underprediction (normalized mean bias $=-79 \%)$ and poor correlation (0.16) when compared to observations. Including MOA in the comparison (red circles in Fig. 3) substantially reduced the model bias (normalized mean bias $=-12 \%$ ) and improved the correlation (0.28). The seasonal plots in Fig. 3 indicate that the reduction in model underprediction at these sites occurred throughout the year. Previous studies showed (see Figs. 3 and 1 from Gantt and Meskhidze, 2013) that without the inclusion of MOA emissions, the largest model underpredictions of clean marine organic aerosol (defined as aerosol that contained black carbon concentrations $<0.05 \mu \mathrm{g} \mathrm{m}^{-3}$ ) concentrations occurred at remote sites in the Southern Ocean and tropical Pacific.

\subsection{Marine organic aerosol aging}

The atmospheric aging of organic aerosols, especially those with a marine source, is not well understood and is an active area of research. In GEOS-Chem, we modeled the aging of MOA based on the e-folding conversion from nascent (hydrophobic) to aged (hydrophilic) in a way similar to terrestrial primary organic aerosols. Tracking the nascent and aged fractions of marine organic aerosol concentrations provided a distribution of their physicochemical characteristics, which could help in identifying locations for future field campaigns. The percentage of aged marine organic 

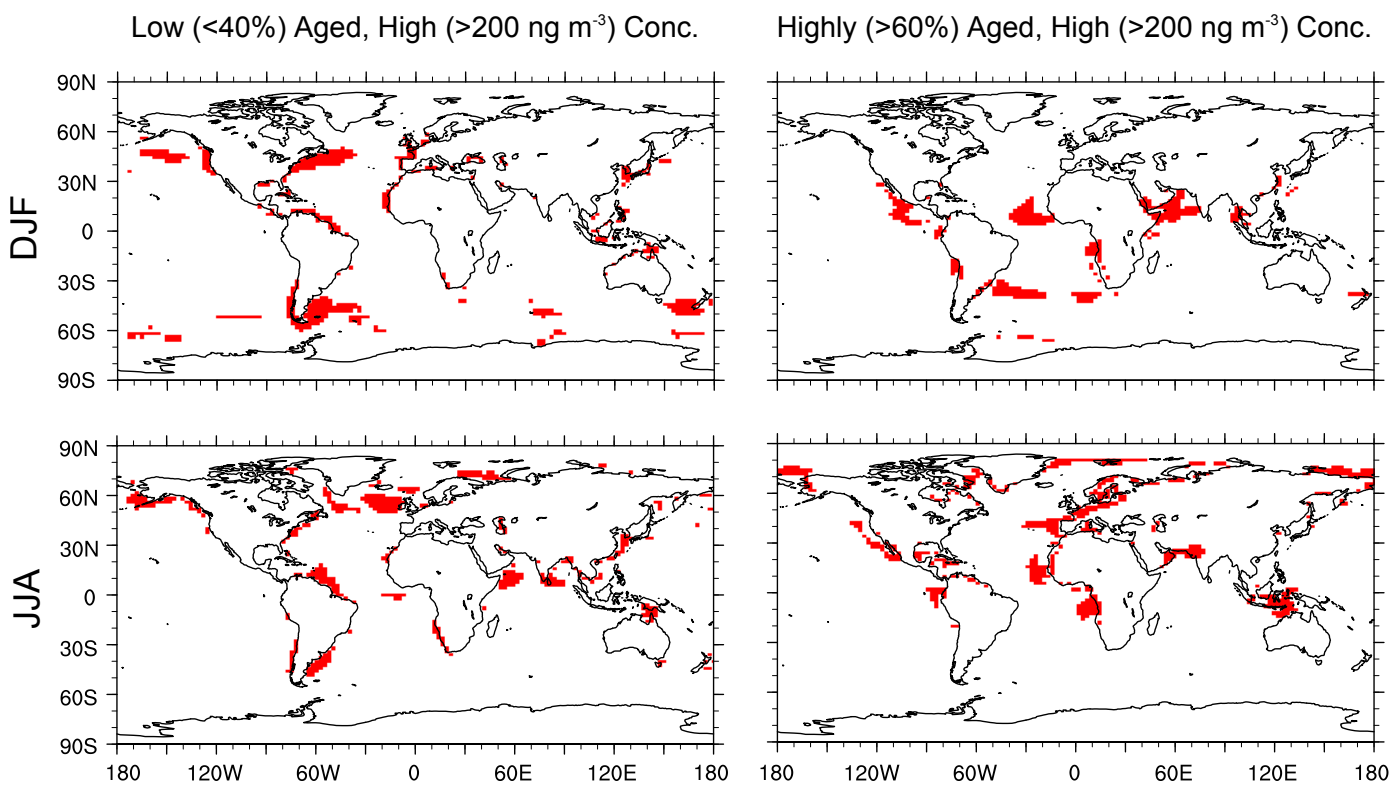

Figure 5. Regions (in red) with GEOS-Chem-predicted seasonal submicron MOA concentrations $>200 \mathrm{ng} \mathrm{m}^{-3}$ for both low-aged (left column, $<40 \%$ hydrophilic marine organic aerosol) and highly aged (right column, $>60 \%$ hydrophilic marine organic aerosol) regimes.

aerosol (hydrophilic/(hydrophilic + hydrophobic) $\times 100$ ) in Fig. 4 shows a strong ocean-continental gradient, with an aged fraction of $40-60 \%$ over the open ocean increasing to nearly $100 \%$ over the continents. As expected, the aged fraction was typically inversely related to the marine POA emission rate (Fig. S1). Gradients between mostly nascent and mostly aged MOAs occurred over oceanic regions as well; the European region inset in Fig. 4 shows the aged fraction increasing from $<40 \%$ in productive waters off the coast of Ireland to $80 \%$ in oligotrophic waters off the coast of Spain. For the Gantt and Meskhidze (2013) clean marine organic aerosol data set, $45 \%$ of the average MOA mass was predicted by GEOS-Chem to be aged.

In addition to having MOAs with a range of atmospheric ages, optimal locations for future field campaigns should have concentrations greater than the detection limit of instrumentation capable of routine monitoring such as the aerosol chemical speciation monitor ( $200 \mathrm{ng} \mathrm{m}^{-3}$ for $30 \mathrm{~min}$ signal averaging; $\mathrm{Ng}$ et al., 2011). Figure 5 segregates areas in which marine organic aerosol mass concentrations greater than $200 \mathrm{ng} \mathrm{m}^{-3}$ were found in both low- and highly aged regimes (arbitrarily chosen as $<40$ and $>60 \%$ aged, respectively) as predicted by GEOS-Chem. For all locations, aging of MOA was based on the e-folding time of 1.15 days; therefore, the temporal and spatial distributions of MOA aging were only controlled by the emissions and transport. Regions with high concentrations of low-aged MOA typically occurred over high ocean productivity regions, while high concentrations of aged MOA were predicted over oligotrophic oceanic regions and inland locations. As many past field campaigns focused on the physical and chemical char- acteristics of marine organic aerosols have taken place in biologically productive coastal areas (Cavalli et al., 2004; Decesari et al., 2011; Russell et al., 2010), nascent MOAs have likely been sampled more frequently than aged aerosols. Regions identified as having a high concentration of aged MOA such as the equatorial Atlantic Ocean and eastern equatorial Pacific Ocean would be good candidates for field campaigns as they likely have MOAs with physicochemical characteristics different than that of nascent aerosols. Figure 5 also identifies regions like the Arabian Sea and Bay of Biscay that had a seasonal cycle of low- and highly aged regimes, making them good candidates for long-term field studies.

\section{Conclusions}

In this work, an online emission parameterization of submicron marine POA has been implemented into the GEOSChem model and evaluated with novel data sets of episodic events and global surface concentrations. This computationally inexpensive marine POA emission scheme includes marine organic aerosol tracers that are independent from terrestrial tracers and treats their hydrophilic-hydrophobic conversion in the atmosphere. The flexibility of this implementation for multiple years/model domains allows users to apply these emissions in the default setting of GEOS-Chem with minimal effort. The comparison with HR-ToF-AMS MOA observations shows that GEOS-Chem replicates the variability (correlation coefficient $=0.62$ ) and magnitude (normalized mean bias $=-36 \%$ ) of summertime concentrations at an inland site near Paris, France. When GEOS-Chem is compared to globally distributed organic aerosol observations in 
clean marine conditions, the underprediction for the default setting of only simulating terrestrial emissions (normalized mean bias $=-79 \%$ ) is reduced with the inclusion of marine POA emissions (normalized mean bias $=-12 \%$ ). In addition to improving the predictions of organic aerosol surface concentrations, the inclusion of marine emissions allows for the prediction of the global distribution of nascent and aged MOA. With the increasing focus on background aerosol concentrations at remote marine, coastal, and inland sites, this emission parameterization has the flexibility and ease of use to be considered for the default setting of global chemical transport/climate models such as GEOS-Chem.

This implementation of marine POA emissions in GEOSChem improves the prediction of clean marine organic aerosol concentrations, although additional drivers of marine POA emissions not considered here (such as oceanic organic carbon, sunlight, and/or organic composition) may be needed to refine the emission scheme in the future (Prather et al., 2013; Quinn et al., 2014; Long et al., 2014). The physicochemical treatment of marine organic aerosol aging identical to that of terrestrial organic aerosols also has large uncertainties, as the processes affecting aerosols in the marine boundary layer have a low level of understanding (Meskhidze et al., 2013). Marine emissions of SOA precursors may also be needed to further reduce the model underprediction of clean marine organic aerosol concentrations. Regardless of future refinements, this implementation of MOA into GEOS-Chem addresses a missing aerosol source, improves the prediction of clean marine and inland marine-sourced organic aerosol concentrations, and enables the model to indicate potential locations for future field studies focused on sampling marine organic aerosols.

\section{The Supplement related to this article is available online at doi:10.5194/gmd-8-619-2015-supplement.}

Acknowledgements. This research was supported by the Office of Science (BER), US Department of Energy grant no. DEFG0208ER64508, National Science Foundation grant no. ATM-0826117, and National Aeronautics \& Space Administration (NASA) through grant no. NNX11AG72G. The measurements in Paris were conducted in the MEGAPOLI project, mainly financially supported by the European Community's Framework Program FP/2007-2011 under grant agreement no. 212520. The authors would like to thank Daniel Jacob and the Harvard University Atmospheric Chemistry Modeling Group for providing the base GEOS-Chem model used during our research. Resources supporting this work were provided by the NASA High-End Computing (HEC) Program through the NASA Advanced Supercomputing (NAS) Division at NASA Ames Research Center. B. Gantt is supported by an appointment to the Research Participation Program at the Office of Research and Development, US EPA, administered by ORISE.
The updated code (GEOS-Chem Fortran and chlorophyll $a$ NetCDF files) is available upon request. Please contact Matthew S. Johnson at matthew.s.johnson@nasa.gov or https://earthscience.arc.nasa.gov/person/Matthew_S_Johnson for more information.

Edited by: G. Mann

\section{References}

Arnold, S. R., Spracklen, D. V., Williams, J., Yassaa, N., Sciare, J., Bonsang, B., Gros, V., Peeken, I., Lewis, A. C., Alvain, S., and Moulin, C.: Evaluation of the global oceanic isoprene source and its impacts on marine organic carbon aerosol, Atmos. Chem. Phys., 9, 1253-1262, doi:10.5194/acp-9-1253-2009, 2009.

Bey, I., Jacob, D. J., Yantosca, R. M., Logan, J. A., Field, B., Fiore, A. M., Li, Q., Liu, H., Mickley, L. J., and Schultz, M.: Global modeling of tropospheric chemistry with assimilated meteorology: Model description and evaluation, J. Geophys. Res., 106, 23073-23095, 2001.

Bigg, E. K. and Leck, C.: The composition of fragments of bubbles bursting at the ocean surface, J. Geophys. Res., 113, D11209, doi:10.1029/2007JD009078, 2008.

Bikkina, S., Kawamura, K., Miyazaki, Y., and Fu, P.: High abundances of oxalic, azelaic, and glyoxylic acids and methylglyoxal in the open ocean with high biological activity: Implication for secondary SOA formation from isoprene, Geophys. Res. Lett., 41, doi:10.1002/2014GL059913, 2014.

Bond, T. C., Bhardwaj, E., Dong, R., Jogani, R., Jung, S., Roden, C., Streets, D. G., and Trautmann, N. M.: Historical emissions of black and organic carbon aerosol from energy-related combustion, 1850-2000, Global Biogeochem. Cy., 21, GB2018, doi:10.1029/2006GB002840, 2007.

Burrows, S. M., Hoose, C., Poschl, U., and Lawrence, M. G.: Ice nuclei in marine air: biogenic particles or dust?, Atmos. Chem. Phys., 13, 245-267, doi:10.5194/acp-13-245-2013, 2013.

Burrows, S. M., Ogunro, O., Frossard, A. A., Russell, L. M., Rasch, P. J., and Elliott, S. M.: A physically based framework for modeling the organic fractionation of sea spray aerosol from bubble film Langmuir equilibria, Atmos. Chem. Phys., 14, 1360113629, doi:10.5194/acp-14-13601-2014, 2014.

Carslaw, K. S., Boucher, O., Spracklen, D. V., Mann, G. W., Rae, J. G. L., Woodward, S., and Kulmala, M.: A review of natural aerosol interactions and feedbacks within the Earth system, Atmos. Chem. Phys., 10, 1701-1737, doi:10.5194/acp-10-17012010, 2010.

Cavalli, F., Facchini, M. C., Decesari, S., Mircea, M., Emblicia, L., Fuzzi, S., Ceburnis, D., Yoon, Y. J., O’Dowd, C. D., Putaud, J.P., and Dell'Acqua, A.: Advances in characterization of size resolved organic matter in marine aerosol over the North Atlantic, J. Geophys. Res., 109, D24215, doi:10.1029/2004JD005137, 2004.

Chang, R. Y.-W., Leck, C., Graus, M., Müller, M., Paatero, J., Burkhart, J. F., Stohl, A., Orr, L. H., Hayden, K., Li, S.M., Hansel, A., Tjernström, M., Leaitch, W. R., and Abbatt, J. P. D.: Aerosol composition and sources in the central Arctic Ocean during ASCOS, Atmos. Chem. Phys., 11, 10619-10636, doi:10.5194/acp-11-10619-2011, 2011. 
Collins, D. B., Ault, A. P., Moffet, R. C., Ruppel, M. J., CuadraRodriguez, L. A., Guasco, T. L., Corrigan, C. E., Pedler, B. E., Azam, F., Aluwihare, L. I., Bertram, T. H., Roberts, G. C., Grassian, V. H., Prather, K. A.: Impact of marine biogeochemistry on the chemical mixing state and cloud forming ability of nascent sea spray aerosol. J. Geophys. Res.-Atmos., 118, 8553-8565, 2013.

Cooke, W. F., Liousse, C., Cachier, H., and Feichter, J.: Construction of a $1 \times 1$ fossil fuel emission data set for carbonaceous aerosol and implementation and radiative impact in theECHAM4 model, J. Geophys. Res., 104, 22137-22162, 1999.

Crippa, M., El Haddad, I., Slowik, J. G., DeCarlo, P. F., Mohr, C., Heringa, M. F., Chirico, R., Marchand, N., Jean, S., Baltensperger, U., and Prévót, A. S. H.: Identification of marine and continental aerosol sources in Paris using high resolution aerosol mass spectrometry, J. Geophys. Res., 118, 1-19, 2013 a.

Crippa, M., Canonaco, F., Slowik, J. G., El Haddad, I., DeCarlo, P. F., Mohr, C., Heringa, M. F., Chirico, R., Marchand, N., Temime-Roussel, B., Abidi, E., Poulain, L., Wiedensohler, A., Baltensperger, U., and Prévôt, A. S. H.: Primary and secondary organic aerosol origin by combined gas-particle phase source apportionment, Atmos. Chem. Phys., 13, 8411-8426, doi:10.5194/acp-13-8411-2013, 2013 b.

Crippa, M., DeCarlo, P. F., Slowik, J. G., Mohr, C., Heringa, M. F., Chirico, R., Poulain, L., Freutel, F., Sciare, J., Cozic, J., Di Marco, C. F., Elsasser, M., Nicolas, J. B., Marchand, N., Abidi, E., Wiedensohler, A., Drewnick, F., Schneider, J., Borrmann, S., Nemitz, E., Zimmermann, R., Jaffrezo, J.-L., Prévôt, A. S. H., and Baltensperger, U.: Wintertime aerosol chemical composition and source apportionment of the organic fraction in the metropolitan area of Paris, Atmos. Chem. Phys., 13, 961-981, doi:10.5194/acp-13-961-2013, 2013c.

DeCarlo, P. F., Kimmel, J. R., Trimborn, A., Northway, M. J., Jayne, J. T., Aiken, A. C., Gonin, M., Fuhrer, K., Horvath, T., Docherty, K. S., Worsnop, D. R., and Jimenez, J. L.: Field-deployable, high-resolution, time-of-flight aerosol mass spectrometer, Anal. Chem., 78, 8281-8289, 2006.

Decesari, S., Finessi, E., Rinaldi, M., Paglione, M., Fuzzi, S., Stephanou, E., Tziaras, T., Spyros, A., Ceburnis, D., O’Dowd, C. D., Dall'Osto, M., Harrison, R., Allan, J., Coe, H., and Facchini, M. C.: Primary and secondary marine organic aerosols over the North Atlantic Ocean during the MAP experiment, J. Geophys. Res., 116, D22210, doi:10.1029/2011JD016204, 2011.

Draxler, R. R. and Rolph, G. D.: HYSPLIT (HYbrid Single-Particle Lagrangian Integrated Trajectory) Model access via NOAA ARL READY Website, available at: http://ready.arl.noaa.gov/ HYSPLIT.php (last access: June, 2014), NOAA Air Resources Laboratory, Silver Spring, MD, 2014.

Facchini, M. C., Rinaldi, M., Decesari, S., Carbone, C., Finessi, E., Mircea, M., Fuzzi, S., Ceburnis, D., Flanagan, R., Nilsson, E., de Leeuw, G., Martino, M., Woeltjen J., and O'Dowd, C. D.: Primary sub-micron marine aerosol dominated by insoluble organic colloids and aggregates, Geophys. Res. Lett., 35, L17814, doi:10.1029/2008GL034210, 2008.

Fountoukis, C. and Nenes, A.: ISORROPIA II: a computationally efficient thermodynamic equilibrium model for $\mathrm{K}^{+}-\mathrm{Ca}_{2}^{+}-\mathrm{Mg}_{2}^{+}-$ $\mathrm{NH}_{4}^{+}-\mathrm{Na}^{+}-\mathrm{SO}_{4}^{2-}-\mathrm{NO}_{3}^{-}-\mathrm{Cl}^{-}-\mathrm{H}_{2} \mathrm{O}$ aerosols, Atmos. Chem. Phys., 7, 4639-4659, doi:10.5194/acp-7-4639-2007, 2007.
Fu, P. Q., Kawamura, K., Chen, J., Charrière, B., and Sempéré, R.: Organic molecular composition of marine aerosols over the Arctic Ocean in summer: contributions of primary emission and secondary aerosol formation, Biogeosciences, 10, 653-667, doi:10.5194/bg-10-653-2013, 2013.

Gantt, B., Meskhidze, N., Facchini, M. C., Rinaldi, M., Ceburnis, D., and O'Dowd, C. D.: Wind speed dependent size-resolved parameterization for the organic mass fraction of sea spray aerosol, Atmos. Chem. Phys., 11, 8777-8790, doi:10.5194/acp-11-87772011, 2011.

Gantt, B., Johnson, M. S., Meskhidze, N., Sciare, J., Ovadnevaite, J., Ceburnis, D., and O'Dowd, C. D.: Model evaluation of marine primary organic aerosol emission schemes, Atmos. Chem. Phys., 12, 8553-8566, doi:10.5194/acp-12-8553-2012, 2012.

Gantt, B. and Meskhidze, N.: The physical and chemical characteristics of marine primary organic aerosol: a review, Atmos. Chem. Phys., 13, 3979-3996, doi:10.5194/acp-13-3979-2013, 2013.

Gong, S.: A parameterization of sea-salt aerosol source function for sub- and super-micron particles, Global Biogeochem. Cy., 17, 1097-1103, 2003.

Hu, Q., Xie, Z., Wang, X-M., Kang H., He, Q-F., and Zhang P.: Secondary organic aerosols over oceans via oxidation of isoprene and monoterpenes from Arctic to Antarctic, Sci. Rep., 3, 2280, doi:10.1038/srep02280, 2013.

Huang, Y., Wu, S., Dubey, M. K., and French, N. H. F.: Impact of aging mechanism on model simulated carbonaceous aerosols, Atmos. Chem. Phys., 13, 6329-6343, doi:10.5194/acp-13-63292013, 2013.

Jaeglé, L., Quinn, P. K., Bates, T. S., Alexander, B., and Lin, J.-T.: Global distribution of sea salt aerosols: new constraints from in situ and remote sensing observations, Atmos. Chem. Phys., 11, 3137-3157, doi:10.5194/acp-11-3137-2011, 2011.

Lanz, V. A., Alfarra, M. R., Baltensperger, U., Buchmann, B., Hueglin, C., and Prévôt, A. S. H.: Source apportionment of submicron organic aerosols at an urban site by factor analytical modelling of aerosol mass spectra, Atmos. Chem. Phys., 7, 15031522, doi:10.5194/acp-7-1503-2007, 2007.

Lapina, K., Heald, C. L., Spracklen, D. V., Arnold, S. R., Allan, J. D., Coe, H., McFiggans, G., Zorn, S. R., Drewnick, F., Bates, T. S., Hawkins, L. N., Russell, L. M., Smirnov, A., O’Dowd, C. D., and Hind, A. J.: Investigating organic aerosol loading in the remote marine environment, Atmos. Chem. Phys., 11, 8847-8860, doi:10.5194/acp-11-8847-2011, 2011.

Long, M. S., Keene, W. C., Kieber, D. J., Frossard, A. A., Russell, L. M., Maben, J. R., Kinsey, J. D., Quinn, P. K., and Bates T. S.: Light-enhanced primary marine aerosol production from biologically productive seawater, Geophys. Res. Lett., 41, 2661-2670, doi:10.1002/2014GL059436, 2014.

Luo, G. and Yu, F.: A numerical evaluation of global oceanic emissions of $\alpha$-pinene and isoprene, Atmos. Chem. Phys., 10, 20072015, doi:10.5194/acp-10-2007-2010, 2010.

Meskhidze, N., Xu, J., Gantt, B., Zhang, Y., Nenes, A., Ghan, S. J., Liu, X., Easter, R., and Zaveri, R.: Global distribution and climate forcing of marine organic aerosol: 1. Model improvements and evaluation, Atmos. Chem. Phys., 11, 11689-11705, doi:10.5194/acp-11-11689-2011, 2011.

Meskhidze, N. Petters, M. D., Tsigaridis, K., Bates, T., O’Dowd, C., Reid, J., Lewis, E. R., Gantt, B., Anguelova, M. D., Bhave, P. V., Bird, J., Callaghan, A. H., Ceburnis, D., Chang, R., Clarke, 
A., de Leeuw, G., Deane, G., DeMott, P. J., Elliot, S., Facchini, M. C., Fairall, C. W., Hawkins, L., Hu, Y., Hudson, J. G., Johnson, M. S., Kaku, K. C., Keene, W. C., Kieber, D. J., Long, M. S., Martensson, M., Modini, R. L., Osburn, C. L., Prather, K. A., Pszenny, A., Rinaldi, M., Russell, L. M., Salter, M., Sayer, A. M., Smirnov, A., Suda, S. R., Toth, T. D., Worsnop, D. R., Wozniak, A., and Zorn, S. R.: Production mechanisms, number concentration, size distribution, chemical composition, and optical properties of sea spray aerosols, Atmos. Sci. Let., 14, 207-213, 2013.

Miyazaki, Y., Sawano, M., and Kawamura, K.: Low-molecularweight hydroxyacids in marine atmospheric aerosol: evidence of a marine microbial origin, Biogeosciences, 11, 4407-4414, doi:10.5194/bg-11-4407-2014, 2014.

Myriokefalitakis, S., Vignati, E., Tsigaridis, K., Papadimas, C., Sciare J., Mihalopoulos, N., Facchini, M.C., Rinaldi, M., Dentener, F. J., Ceburnis, D., Hatzianastasiou, N., O’Dowd, C. D., van Weele, M., and Kanakidou, M.: Global modelling of the oceanic source of organic aerosols, Adv. Meteorol., 2010, 939171, doi:10.1155/2010/939171, 2010.

Ng, N. L., Herndon, S. C., Trimborn, A., Canagaratna, M. R., Croteau, P., Onasch, T. M., Sueper, D., Worsnop, D. R., Zhang, Q., Sun, Y. L., and Jayne, J. T.: An Aerosol Chemical Speciation Monitor (ACSM) for routine monitoring of atmospheric aerosol composition, Aerosol Sci. Technol., 45, 770-784, 2011.

O’Dowd, C. D., Facchini, M. C., Cavalli, F., Ceburnis, D., Mircea, M., Decesari, S., Fuzzi, S., Yoon, Y. J., and Putaud, J. P.: Biogenically driven organic contribution to marine aerosol, Nature, 431, 676-680, 2004.

O’Dowd, C. D., Langmann, B., Varghese, S., Scannell, C., Ceburnis, D., and Facchini, M. C.: A combined organic-inorganic sea-spray source function, Geophys. Res. Lett., 35, L01801, doi:10.1029/2007GL030331, 2008.

Ovadnevaite, J., O'Dowd, C., Dall'Osto, M., Ceburnis, D., Worsnop, D. R., and Berresheim, H.: Detecting high contributions of primary organic matter to marine aerosol: a case study, Geophys. Res. Lett., 38, L02807, doi:10.1029/2010GL046083, 2011.

Park, R. J., Jacob, D. J., Field, B. D., Yantosca, R. M., and Chin, M.: Natural and transboundary pollution influences on sulfate-nitrate-ammonium aerosols in the United States: implications for policy, J. Geophys. Res., 109, D15204, doi:10.1029/2003JD004473, 2004.

Partanen, A.-I., Dunne, E. M., Bergman, T., Laakso, A., Kokkola, H., Ovadnevaite, J., Sogacheva, L., Baisnée, D., Sciare, J., Manders, A., O'Dowd, C., de Leeuw, G., and Korhonen, H.: Global modelling of direct and indirect effects of sea spray aerosol using a source function encapsulating wave state, Atmos. Chem. Phys., 14, 11731-11752, doi:10.5194/acp-14-11731-2014, 2014.

Prather, K. A., Bertram, T. H., Grassian, V. H., Deane, G. B., Stokes, M. D., DeMott, P. J., Aluwihare, L. I., Palenik, B. P., Azam, F., Seinfeld, J. H., Moffet, R. C., Molina, M. J., Cappa, C. D., Geiger, F. M., Roberts, G. C., Russell, L. M., Ault, A. P., Baltrusaitis, J., Collins, D. B., Corrigan, C. E., Cuadra-Rodriguez, L. A., Ebben, C. J., Forestieri, S. D., Guasco, T. L., Hersey, S. P., Kim, M. J., Lambert, W. F., Modini, R. L., Mui, W., Pedler, B. E., Ruppel, M. J., Ryder, O. S., Schoepp, N. G., Sullivan, R. C., and Zhao, D.: Bringing the ocean into the laboratory to probe the chemical complexity of sea spray aerosol, P. Natl. Acad. Sci. USA, 110, 7550-7555, doi:10.1073/pnas.1300262110, 2013.

Pye, H. O. T., Chan, A. W. H., Barkley, M. P., and Seinfeld, J. H.: Global modeling of organic aerosol: the importance of reactive nitrogen (NOx and NO3), Atmos. Chem. Phys., 10, 1126111276, doi:10.5194/acp-10-11261-2010, 2010.

Quinn, P. K., Bates, T. S., Schulz, K. S., Coffman, D. J., Frossard, A. A., Russell, L. M., Keene, W. C., and Kieber, D. J.: Contribution of sea surface carbon pool to organic matter enrichment in sea spray aerosol, Nat. Geosci., 7, 228-232, doi:10.1038/ngeo2092, 2014.

Rinaldi, M., Facchini, M. C., Decesari, S., Carbone, C., Finessi, E., Mircea, M., Fuzzi, S., Ceburnis, D., Ehn, M., Kulmala, M., de Leeuw, G., and O'Dowd, C. D.: On the representativeness of coastal aerosol studies to open ocean studies: Mace Head - a case study, Atmos. Chem. Phys., 9, 9635-9646, doi:10.5194/acp-99635-2009, 2009.

Rinaldi, M., Decesari, S., Finessi, E., Giulianelli, L., Carbone, C., Fuzzi, S., O’Dowd, C. D., Ceburnis, D., and Facchini,M. C.: Primary and secondary organic marine aerosol and oceanic biological activity: Recent results and new perspectives for future studies, Adv. Meteorol., 2010, 310682, doi:10.1155/2010/310682, 2010.

Rinaldi, M., Fuzzi, S., Decesari, S., Marullo, S., Santoleri, R., Provenzale, A., von Hardenberg, J., Ceburnis, D., Vaishya, A., O'Dowd, C. D., and Facchini, M. C.: Is chlorophyll-a the best surrogate for organic matter enrichment in submicron primary marine aerosol?, J. Geophys. Res. Atmos., 118, 4964-4973, doi:10.1002/jgrd.50417, 2013.

Russell, L. M., Hawkins, L. N., Frossard, A. A., Quinn, P. K., and Bates, T. S.: Carbohydrate-like composition of submicron atmospheric particles and their production from ocean bubble bursting, P. Natl. Acad. Sci. USA, 107, 6652-6657, doi:10.1073/pnas.0908905107, 2010.

Schmale, J., Schneider, J., Nemitz, E., Tang, Y. S., Dragosits, U., Blackall, T. D., Trathan, P. N., Phillips, G. J., Sutton, M., and Braban, C. F.: Sub-Antarctic marine aerosol: dominant contributions from biogenic sources, Atmos. Chem. Phys., 13, 86698694, doi:10.5194/acp-13-8669-2013, 2013.

Sciare, J., Favez, O., Sarda-Estève, R., Oikonomou, K., Cachier, H., and Kazan, V.: Long-term observations of carbonaceous aerosols in the Austral Ocean atmosphere: Evidence of a biogenic marine organic source, J. Geophys. Res., 114, D15302, doi:10.1029/2009JD011998, 2009.

Shaw, S. L., Gantt, B., and Meskhidze, N.: Production and emissions of marine isoprene and monoterpenes, A review, Adv. Meteorol., 24, 408696, doi:10.1155/2010/408696, 2010.

Sinreich, R., Coburn, S., Dix, B., and Volkamer, R.: Ship-based detection of glyoxal over the remote tropical Pacific Ocean, Atmos. Chem. Phys., 10, 11359-11371, doi:10.5194/acp-1011359-2010, 2010.

Spracklen, D. V., Arnold, S. R., Carslaw, K. S., Sciare, J., and Pio, C.: Globally significant oceanic source of organic carbon aerosol, Geophys. Res. Lett., 35, L12811, doi:10.1029/2008GL033359, 2008.

Tsigaridis, K., Koch, D., and Menon, S.: Uncertainties and importance of sea spray composition on aerosol direct and indirect effects, J. Geophys. Res., 118, 220-235, 2013. 
van der Werf, G. R., Randerson, J. T., Giglio, L., Collatz, G. J., Mu, M., Kasibhatla, P. S., Morton, D. C., DeFries, R. S., Jin, Y., and van Leeuwen, T. T.: Global fire emissions and the contribution of deforestation, savanna, forest, agricultural, and peat fires (19972009), Atmos. Chem. Phys., 10, 11707-11735, doi:10.5194/acp10-11707-2010, 2010.

Vignati, E., Facchini, M. C., Rinaldi, M., Scannell, C., Ceburnis, D., Sciare, J., Kanakidou, M., Myriokefalitakis, S., Dentener, F., and O'Dowd, C. D.: Global scale emission and distribution of seaspray aerosol: sea-salt and organic enrichment, Atmos. Environ., 44, 670-677, 2010.

Wesely, M. L.: Parameterization of surface resistances to gaseous dry deposition in regional-scale numerical-models, Atmos. Environ., 23, 1293-1304, 1989.

Westervelt, D. M., Moore, R. H., Nenes, A., and Adams, P. J.: Effect of primary organic sea spray emissions on cloud condensation nuclei concentrations, Atmos. Chem. Phys., 12, 89-101, doi:10.5194/acp-12-89-2012, 2012.
Zare, A., Christensen, J. H., Gross, A., Irannejad, P., Glasius, M., and Brandt, J.: Quantifying the contributions of natural emissions to ozone and total fine PM concentrations in the Northern Hemisphere, Atmos. Chem. Phys., 14, 2735-2756, doi:10.5194/acp14-2735-2014, 2014.

Zhang, L. M., Gong, S. L., Padro, J., and Barrie, L.: A sizesegregated particle dry deposition scheme for an atmospheric aerosol module, Atmos. Environ., 35, 549-560, 2001.

Zhang, Q., Jimenez, J., Canagaratna, M., Ulbrich, I., Ng, N., Worsnop, D., and Sun, Y. L.: Understanding atmospheric organic aerosols via factor analysis of aerosol mass spectrometry: a review, Anal. Bioanal. Chem., 401, 3045-3067, 2011. 